\title{
Legal and practical aspects of establishing servitude of right of way by court judgment within the framework of urban and rural development and changing global conditions
}

\author{
Jolanta Dinsberga* and Valdis Savickis \\ Rīga Stradinsš University, Faculty of Law, Riga, Latvia
}

\begin{abstract}
As a result of urban and rural development new land areas are being acquired. However, many proprietors face challenges in terms of inability to access their immovable properties due to the reason that they are not adjacent to public roads. One of the ways how a person can acquire the right to use his or her property is to request a court to determine servitude of right of way to access the property. The goal of this study is as follows: to identify the problems of the described topic, to draw conclusions and to offer solutions to solve the identified problems by studying the legal framework of establishing servitude of right of way and the specific features of the application thereof. Methodology applied in the study: 1) general scientific - descriptive, analytical, modelling, dogmatic, deductive, and inductive; 2) interpretation of legal norms - grammatical, systematic, and teleological. Issues covered in the study: jurisdiction of the disputes over servitude of right of way; time limits for dispute resolution by courts; and impact of the initiation of insolvency proceedings on the progress of cases related to establishing servitude of right of way by a court. The following conclusions were drawn by the authors at the end of the study: global changes generate the necessity to facilitate urban and rural development in Latvia, inter alia, to tackle the issues of property accessibility.
\end{abstract}

Key words: servitude of right of way, land reform, public road, property rights.

\section{Introduction}

In 2010, according to the assignment given by the Ministry of Regional Development and Local Government of Latvia, the group of experts headed by R. Ķilis developed the Sustainable Development Strategy of Latvia until 2030 (Latvija 2030) (hereinafter - Latvija 2030). After approval thereof at the Saeima on 10 June 2010 [1], the elaborated Strategy became the primary national planning instrument having statutory effect. It is stated in Paragraph 270 of Latvija2030 that "Latvia is a relatively small country with limited economic and natural resources, therefore national competitiveness and development in the most direct way are linked with the ability to follow up and to adapt rapidly to global changes by using its privileges in the most efficient way" [2]. In the opinion of authors, global changes force the country to move forward and serve as a constant driving force for continuous development of urban and rural areas of Latvia. According to Paragraphs 331 and 332 of

\footnotetext{
* Corresponding author: dinsbija@gmail.com
}

(C) The Authors, published by EDP Sciences. This is an Open Access article distributed under the terms of the Creative Commons Attribution License 4.0 (http://creativecommons.org/licenses/by/4.0/). 
the aforementioned Strategy, "The interaction between urban and rural areas gives greater opportunities to the population and diversifies access to high-quality environment regardless of the place of residence [..]" [3]. Evidently, one can agree that urban and rural development cannot be attained separately from each other. The mutual interaction of urban and rural areas is one of the key development factors. Therefore, also Latvija2030 authors emphasise that by using specific advantages of each territory and by addressing the challenges jointly, various interaction directions of both urban and rural areas will increase where the opportunities for mobility would be one of such directions, inter alia, ensuring access of the population of rural areas to development centres, as well as generating opportunities for the sale of agricultural and forestry products as specified in Paragraphs 333 and 334. It must be noted that the aforementioned also correlates with Paragraphs 278-307 of Latvija2030 which define the improvement of accessibility, for example, the improvement of external and internal accessibility, development of paths and solutions in planning transport infrastructure, and planning of the road network, etc. It is forecast that over $80 \%$ of Europeans will be living in urban areas in 2030 alongside with the ageing of the population and increase in immigration flows. It is therefore essential to consider health and welfare matters in such areas as urban planning, construction, land use, transport, [..] a.o. [4] not only in the national planning documents, but also in urban management.

According to authors, it is impossible to achieve the strategic goals defined in the highestlevel national planning documents and to perform the tasks subordinated to the achievement of these goals if even seemingly insignificant problems are not prevented in certain areas of law. The authors, therefore, in this publication offer a brief analytical view of the problems in Latvia in particular in relation to accessibility issues (ensuring access to immovable properties) that must be addressed within the scope of implementing Latvija2030. Only then Latvia will be able to integrate and participate fully in the already mentioned global environment.

Accordingly, as a result of rural development [5] and urban development [6], new territories of land are constantly being acquired, industrial, agricultural and forestry sectors experience development, intensive trade of immovable property takes place in Latvia [7].

However, in the context of the aforementioned processes immovable property owners are facing problems related to inability to access their property due to the reason that they are not adjacent to public roads, and the only way to access the property is to use the plot of land included in the adjacent immovable property. In order to obtain an overview of the nature of problems and the external manifestation thereof, authors would like to name the following examples:

1) The owners of adjacent plots of land do not agree voluntarily to authorise access to their immovable properties, even if they realise that the neighbour has no other possibility to access the property;

2) Even in cases where the road leading to the immovable property is planned according to an administrative act (but has not been built yet), it is marked as an encumbrance in the relevant urban planning documents and the land border plan of the adjacent immovable property, the owner of the adjacent immovable property precludes the possibility to move around the plot of land and refuses to agree thereon voluntarily;

3) The person whose consent is required to cross the plot of land owned is absent or cannot be reached. Consequently, the consent cannot be obtained;

4) In situations where insolvency proceedings/legal protection proceedings of the owner of the adjacent immovable property - a natural or legal person - are initiated, the solution of the issue related to ensuring access rights may take some time or stop 
completely as this person no longer has the right of action and all decisions related to encumbering immovable property with property rights is taken by an insolvency administrator;

5) At the time when land reform was implemented in Latvia, when restoring proprietary rights to nationalised properties to the owners or heirs thereof, as well as transferring immovable properties for privatisation, the State Land Service, land commissions and local governments were entitled to decide on ensuring access to the immovable property [8]. The aforementioned entities established numerous servitudes of right of way on the basis of an administrative act, and these servitudes are corroborated in the Land Register in the form of a remark, instead of an entry. Due to the legal loopholes of such decisions and remarks, currently the servitudes of right of way recorded in the Land Register in the form of a remark cannot be recognised as effective and the owners of adjacent immovable properties have a legal basis to prohibit entrance in their property. ${ }^{1}$

The abovementioned and other cases which are not mentioned in the study cause the restriction of the right to own property referred to in Article 105 of the Constitution of the Republic of Latvia [9], and frequently also significant material losses to the owners of immovable properties that are not adjacent to public roads. For instance, a farmer who is involved in grain cultivation may face losses with all the resulting consequences, considering that the farmer cannot access his or her property and to harvest the crops in due time;; an entrepreneur cannot deliver the goods manufactured in its factory to the customer if the new owner of the adjacent territory near the exit from the territory builds a fence along the border without any warning. It must be noted that this causes losses not only to immovable property owners, but also to national economy - as a result of discontinuing or terminating the economic activity, taxes payable within the scope of the economic activity will not be transferred to State budget.

In the aforementioned situations a certain mechanism to ensure access rights is stipulated in the laws and regulations of Latvia. This mechanism is governed quite comprehensively. Servitude of right of way must be established so that a person could access his or her immovable property. It is stated in Section 1130 of the Civil Law that "Servitude is such right in respect of the property of another as restricts ownership rights regarding it, with respect to utilisation, for the benefit of a certain person or a certain parcel of land" [10]. It should be noted that encumbered immovable property is referred to as a servient immovable property, whereas immovable property in favour of which servitude is being establisheda dominant immovable property. By means of servitude of right of way rights may be granted: 1) to a footpath; 2) to a livestock path; and 3) to a roadway [10]. If servitude of right of way is not established by law, a contract or a will, it shall be established by a court.

In view of the aforementioned, authors set forth the following goal of the study: to identify the problems of the described topic, to draw conclusions and to offer solutions to solve the identified problems by studying the legal framework of establishing a servitude of right of way and the specific features of the application thereof.

\footnotetext{
${ }^{1}$ Information on a more extensive analytical study on servitudes established by administrative acts and related problems in Latvia is available at: Dinsberga, J. Bite K. Legal consequences and problems of the servitudes of right of way established by administrative acts in Latvia. 6th International Interdisciplinary Scientific Conference SOCIETY HEALTH. WELFARE. SHS Web of Conferences 40, 01011 (2018)
} 
Due to limited size, the study covers only a few problems identified during legal proceedings and suggests potential solutions thereof.

\section{Research materials}

The study is based upon the analysis of laws and regulations, case-law and conclusions drawn by specialists in the field of civil law. The following legislative acts are used in the study: Civil Law, Constitution of the Republic of Latvia, Insolvency Law, Latvija2030. Document analysis and case analysis were used as primary data of the study. In addition, the following was used as secondary data: study by Mārtiņš Auders on servitudes of right of way established by administrative acts during land reform conducted in 2014; conclusions expressed by specialists in the field of civil law from the book by E. Kalniņš (2005) and the article by E. Meļ̧isisis included in a collection of articles (2003). The study is based upon a case analysis and unpublished documents were analysed as part of the case analysis.

\section{Methods}

General scientific study methods: Descriptive - by identifying the existing problems in relation to access possibilities to immovable properties, studying the legal framework for establishing servitudes of right of way, compiling information and relying on study results and providing explanations. Analytical - by studying laws and regulations, caselaw, opinions of specialists in the field of civil law in order to identify problems in the context of the matters examined in the study from different aspects. Dogmatic - by conducting a comprehensive analysis of the legal framework that defines development areas of Latvia, determination of servitude by a judgment of a court, insolvency and legal protection proceedings. Modelling potential situations and resolving them basing on the newly created legal norms, offered by the authors of the study. Induction and deduction - by expressing separate judgments during the entire study.

The methods of interpretation of legal norms have been also applied in the study: Grammatical - by examining the meaning and substance of the notions included in legal norms, assessing legal norms from the grammatical aspect. Systematic - by examining the procedures for establishing servitude of right of way in the Civil Law in conjunction with other laws and regulations governing the determination of servitudes of right of way. Teleological - by examining the intention of the legislator when adopting laws and regulations related to establishing servitudes of right of way.

\section{Results and discussion}

\subsection{Subordination of disputes over establishing servitude of right of way}

Servitudes may be established: 1) by law; 2) by a judgment of a court; 3) by a contract or a will [10]. The establishing of servitude of right of way by a judgment of a court is a measure of last resort for establishing property rights. The disputes over establishing servitude of right of way are qualified as disputes under civil law. The allocation and jurisdiction of civil legal disputes are governed by Chapter 3 of the Civil Procedure Law. It is stated in Section 23 of the aforementioned Law that "All civil legal disputes shall be allocated to the court, unless otherwise provided for in law." This shall not deprive the parties of the right to apply, upon mutual agreement, to an arbitration court or to use mediation in order to settle a dispute" [11]. It is apparent from the content of the mentioned Section that civil legal disputes can be 
subject to resolution by a general jurisdiction court and also by other institutions. Although Section 23 of the Civil Procedure Law refers to the right of the parties "to apply, upon mutual agreement, to an arbitration court or to use mediation in order to settle a dispute", it should be noted that in Latvia claims for establishing servitude of right of way are submitted to and resolved by a general jurisdiction court. Unfortunately, authors could not find judgments on establishing servitude of right of way which would be delivered by an arbitration court. In view of this, authors are wondering why the belief that servitudes-related issues are to be resolved by a general jurisdiction court prevails in Latvia. It is likely that this mistaken belief derives from Section 5, Paragraph one, Clause 5 of the Arbitration Law which prescribes the competence of an arbitration court "(1) An arbitration court shall resolve any civil legal disputes, provided that the parties have voluntarily agreed upon and concluded an arbitration agreement, except for the following dispute: [..] 5) over the establishment, alteration or termination of property rights in regard to immovable property, if a party to the dispute is a person whose rights to acquire the immovable property for ownership, possession or use are restricted by law; [..]" [12]. While analysing the mentioned legal norm, authors came to the conclusion that arbitration courts have the right to resolve issues related to the establishment, termination or alteration of servitude of right of way. Though servitude is a property right that can be said to be linked with Section 5, Paragraph one, Clause 5 of the Law, when interpreting this Clause according to the method of grammatical interpretation, it is understandable that the focus is kept on persons without the right to obtain the immovable property in ownership, possession or use. It can be therefore concluded that this Clause is applicable to a narrow range of persons. And, if such a restriction does not exist in relation to a party to the dispute, the dispute is to be resolved also by an arbitration court. For instance, when analysing the contract concluded between persons " $\mathrm{S}$ " and "M" [13], authors discovered that "S" and "M" have agreed to establish servitude of right of way in the future. Clause 3 of the contract states that "If "M" purchases the immovable property under cadastre No. [..], located in [..], the parties undertake to conclude the contract on establishing a servitude of right of way, agreeing on the length, width, location of a servitude of right of way and other mutually beneficial and acceptable conditions to the parties". The parties have the right to conclude a transaction on establishing a servitude of right of way in the future in accordance with Section 1413 of the Civil Law, which prescribes the following: "[..] a transaction may also apply to future property" [14]. In addition, "S" and " $\mathrm{M}$ " have included an arbitration clause in the contract that is a precondition for the dispute to be resolved by an arbitration court. Consequently, if "S", who is the owner of the servient immovable property, refuses to conclude the contract on establishing servitude of right of way after the property has been purchased by " $\mathrm{M}$ ", "M" would have the right to address to an arbitration court with the request to conclude the contract on establishing the servitude of right of way. Furthermore, Section 1587 of the Civil Law stipulates as follows: "A contract legally entered into shall impose on a contracting party a duty to perform that which was promised" [14]. Of course, according to Section 24, Paragraph one of the Arbitration Law, "The arbitration panel, upon receipt of an application for a claim, shall decide on the arbitral jurisdiction of a civil legal dispute [..]", assessing whether the dispute is within arbitral jurisdiction and there are no other exceptions for the resolution of disputes referred to in Section 5 of the Arbitration Law. Different regulatory framework and approach in resolving issues concerning the jurisdiction of the dispute over establishing servitude of right of way exist in the Russian Federation. In accordance with the Code of Administrative Judicial Procedure of the Russian Federation disputes of economic nature and other matters related to commercial activities and other economic activities are within arbitral jurisdiction [15]. According to the case-law collection of the Supreme Court of the Russian Federation, when resolving a matter on the allocation of a case on a servitude 
of right of way either to a general jurisdiction court or an arbitration court, the status of the subject of the dispute has the decisive moment in this regard.

\subsection{Duration of dispute resolution at courts}

In accordance with the principle of procedural economy enshrined in Section 28 of the law On Judicial Power "A judge shall try a matter as fast as possible" [16]. The case-law of the Supreme Court of the Republic of Latvia is summarised by authors in the table below: judgments in cases related to the establishment of a servitude of right of way delivered by the Civil Cases Department of the Senate of the Supreme Court for the purpose of determining the duration of the resolution of cases of the referred to category from the moment a judgment has been delivered by a court of first instance until the moment a judgment is delivered by the Civil Cases Department of the Senate of the Supreme Court. Authors did not select and analyse all judgments delivered by a court of first instance and appellate instance court, as it is believed that the number of judgments is sufficient to obtain sufficient information and to obtain basis to draw conclusions and to identify problems related to duration of the resolution of cases at courts.

Based on the analysis of court judgments specified in the table above, authors conclude that the resolution of disputes in relation to the establishment of servitude of right of way on average lasts for a period of 3 years from the moment a judgment has been delivered by a court of first instance until the moment a judgment is delivered by the Civil Cases Department of the Senate of the Supreme Court. The time of examination of the case by court of first instance can last from one to four years (authors' experience), and it is excluded from this period. The period when the case is re-examined by an appellate instance court is excluded, too. Out of six court judgments included in the table above, five court judgments have been revoked either in full or in part and referred for re-examination by an appellate instance court. This means that the duration of the resolution of a case is extended. The analysis resulted in authors' conclusion that cases related to establishing servitude of right of way are examined excessively long. In this period, the right to own property of the owners of dominant immovable properties stipulated in Article 105 of the Constitution of the Republic of Latvia and also Article 1 of Protocol No. 1 to the Convention for the Protection of Human Rights and Fundamental Freedoms [23] is breached, i.e., completely "paralysed" due to the reason that in the course of legal proceedings there is no access to the immovable property and it is not possible to use the property. This legal situation where a property cannot be used over several years only due to the flaws in laws and regulations that leads to inability to ensure unimpeded access to any immovable property is not acceptable to contemporary society and is not typical to this era. It is therefore necessary to introduce a legal mechanism whereby the respective deficiency can be rectified.

At authors' disposal there are documents that indicate to the first attempts of lawyers to seek a temporary solution and to ensure temporary access possibilities to the immovable property in the course of the legal proceedings related to establishing servitude of right of way. The dispute is based upon the fact that the plaintiff "A.R." has purchased immovable property that could be accessed by crossing the immovable property owned by "I.B." along the territory intended for servitude of right of way. "I.B." prohibited "A.R.।" from using the territory of servitude of right of way.

At the moment when the immovable property was purchased, "A.R." relied on the territory of a servitude of right of way being recorded in the plan of immovable property borders, layout and encumbrances and the part of the Land Register, and was convinced that only agreement on the procedures for the right of use of a servitude of right of way 
Table 1. Judgments by the Civil Cases Department of the Senate of the Supreme Court in cases related to establishing servitudes of right of way [by authors].

\begin{tabular}{|c|c|c|}
\hline $\begin{array}{l}\text { Duration of legal } \\
\text { proceedings } \\
\text { calculated in } \\
\text { years }\end{array}$ & $\begin{array}{l}\text { Date of a judgement } \\
\text { by district (city) } \\
\text { courts }\end{array}$ & $\begin{array}{l}\text { Date of the judgment by the Civil Cases } \\
\text { Department of the Senate of the Supreme } \\
\text { Court of the Republic of Latvia } \\
\text { Resolved as follows: }\end{array}$ \\
\hline $\begin{array}{l}\text { longer } \\
\text { than } 3\end{array}$ & $\begin{array}{l}\text { Balvi District Court - } \\
05.12 .2014\end{array}$ & $\begin{array}{l}04.07 .2017 \text {, judgment in case No. C09030814 } \\
\text { SKC 229/2017 [17] } \\
\text { To revoke the judgment of } 16.03 .2015 \text { by the Civil } \\
\text { Matters Division of Latgale Regional Court and } \\
\text { to refer the case for re-examination thereof by an } \\
\text { appellate instance court. }\end{array}$ \\
\hline longer than 3 & $\begin{array}{l}\text { City of Riga Central } \\
\text { District } \\
\text { Court }-08.10 .2012 \\
\text { (action brought on } \\
06.09 .2010 \text { ) }\end{array}$ & $\begin{array}{l}12.04 .2016 \text {, judgment in case No. C } 27209810 \\
\text { SKC- } 33 / 2016 \text { [18] } \\
\text { To revoke the appealed part of the judgment } \\
\text { of } 08.04 .2013 \text { by the Civil Matters Division of } \\
\text { Riga Regional Court and to refer the case for } \\
\text { re-examination thereof by an appellate instance } \\
\text { court. }\end{array}$ \\
\hline 3 & $\begin{array}{l}\text { Ventspils City Court - } \\
31.03 .2011 \\
\text { (action brought on } \\
\text { 16.10.2010) }\end{array}$ & $\begin{array}{l}31.03 .2014 \text {, judgment in case No. SKC-11/2014 } \\
\text { [19] To uphold the judgment of } 04.01 .2012 \text { by } \\
\text { the Civil Matters Division of Kurzeme Regional } \\
\text { Court, but to reject the cassation complaint of A.R. }\end{array}$ \\
\hline almost 3 & $\begin{array}{l}\text { Daugavpils City } \\
\text { Court }-19.10 .2011 \\
\text { (action brought on } \\
28.05 .2010)\end{array}$ & $\begin{array}{l}09.10 .2013 \text {, judgment in case No. SKC- } 458 / 2013 \\
\text { [20] To revoke the judgment of } 02.02 .2012 \text { by the } \\
\text { Civil Matters Division of Latgale Regional Court } \\
\text { in the part where the claim is satisfied and the } \\
\text { counter-claim is rejected, and to refer the case in } \\
\text { this part for re-examination thereof by an appellate } \\
\text { instance court. }\end{array}$ \\
\hline longer than 1 & $\begin{array}{l}\text { Preili District Court - } \\
\text { 28.02.2008 }\end{array}$ & $\begin{array}{l}\text { 12.08.2009, judgment in case No. SKC }-192[21] \\
\text { To revoke the judgment of } 27.01 .2007 \text { by the Civil } \\
\text { Matters Division of Vidzeme Regional Court and } \\
\text { to refer the case for re-examination thereof by an } \\
\text { appellate instance court. }\end{array}$ \\
\hline less than 1 & $\begin{array}{ll}\text { Valmiera } & \text { District } \\
\text { Court }-19.08 .2004\end{array}$ & $\begin{array}{l}08.06 .2005 \text {, judgment in case No. C39125103 } \\
\text { SKC-320/2005[22] } \\
\text { To revoke the judgment of } 27.01 .2005 \text { by the Civil } \\
\text { Matters Division of Vidzeme Regional Court and } \\
\text { to refer the case for re-examination thereof by an } \\
\text { appellate instance court. }\end{array}$ \\
\hline
\end{tabular}

with "I.B." would be required. Moreover, when dividing and merging immovable properties in accordance with the laws and regulations effective in the Republic of Latvia (Cabinet Regulation No. 182 of 20 March 2007, Regulations Regarding Specification of an Immovable Property Object [24], Binding Regulation No. 60 of 27 April 2006, Graphical Display of the Spatial Plan of Ogre Municipality and Regulations Regarding the Use and Construction of the Territory of Ogre Municipality [25]), it was necessary to provide for access to the divided immovable property. The property of "A.R." emerged as a result of actual division of the immovable property owned by the mother of "I.B.". The territory of the respective servitude has been marked off in the land border plan of the servient immovable property and in the form of a remark in the Land Register as an encumbrance based on an administrative act regarding the division of the immovable property into actual units and determining of the address. However, the latter does not give the right to move across the respective plot of land, because as the result of dividing the plot of land the territory of servitude of right of 
way is planned for access, but the contract thereon has not been concluded between "I.B." and "A.R.".

When interpreting the norms of the aforementioned regulations according to the method of historical and teleological interpretation, it can be concluded that the goal set by the legislator in regard to the actual division of the immovable property was to ensure to the owners of divided immovable properties unimpeded use of the property and access thereto. Unfortunately, the legislator has not regulated all aspects of these matters. In the opinion of authors, the fact that the territory of the planned servitude of right of way is determined in an administrative act does not impose an obligation on the owner of the servient immovable property to conclude the contract on establishing servitude of right of way with the owner of the dominant immovable property. From the point of view of authors, the norms adopted by the legislator only serve as the so-called "formal reference" which has the informative role. This may be also classified as a "legislative gap", because the attempts of the legislator to regulate the particular situation do not work in practice and the respective norms do not fulfil their function.

The request to take a provisional decision in a civil case on establishing servitude of right of way was submitted to Zemgale District Court (Ogre) on 26 September 2018 [26]. In the respective request it was demanded to take a provisional decision and, until giving the final judgment, to determine access to the immovable property on foot or by means of transport [..] of the immovable property to be used [..] land border of 18 April 2008, territory of a servitude of right of way marked off in the plan of the layout and encumbrances (area of 0.16 ha, length: 300 meters, width: 4.5 meters). The request was grounded by "A.R." with a "legislative gap" in the legal framework and "A.R." also referred to Section 5, Paragraph five of the Civil Procedure Law that states: "If there is no law governing the contested relation, a court shall apply a law governing similar legal relations, but if no such law exists, a court shall act in accordance with general legal principles and meaning”. However, Paragraph six of the referred to Section of the Law stipulates as follows: "In applying legal norms, a court shall take into account the case law" [27]. "A.R." also mentioned in the request that "in individual cases the Civil Procedure Law allows taking of a provisional decision until the giving of a judgment". It is stated in Section 238. ${ }^{1}$, Paragraph one of the Civil Procedure Law that "(1) Upon a request of a party a court or judge may take a decision which temporarily, until the judgment on divorce or annulment of marriage is given, specifies the place of residence of the child, the procedures for child care, the procedures for exercising access rights, child maintenance, prohibition to taking the child out of the State, means for the provision of the previous welfare level of the spouse, procedures for use of the joint home of the spouses or instructs one of the parties to issue to the other party household and personal articles." Furthermore, also Section 244. ${ }^{10}$, Paragraph one and Section 267. ${ }^{1}$, Paragraph one of the Civil Procedure Law provides for taking a provisional decision upon request of a party.

Just like taking of a provisional decision, Section 238. ${ }^{1}$, Paragraph one, Section 244. ${ }^{10}$, Paragraph one, and Section 267. ${ }^{1}$, Paragraph one of the Civil Procedure Law stipulates and safeguards the legitimate interest of particular persons until the final judgment, also "A.R." requires a provisional regulation to ensure the guaranteed rights to the property thereof [27].

E. Melķisis shares the following opinion: "Considering that the court has identified a lack of regulation, there are grounds to discuss the matter on the existence of a legislative gap and elimination of this gap. As stated in the legal doctrine, there exists a legislative gap if the law, considering the interpretation thereof, does not cover positive legal framework, even though such regulation is necessary from the point of view of the legal system [28].

E. Kalniņš indicates: "The legislative gap can be identified if the law in respect of the particular group of occasions does not cover positive legal framework, even though such 
regulation should have been covered therein, considering the plan and objective of the respective law. The identified legislative gap can be eliminated by analogy" [29].

Having assessed the quoted conclusions expressed by prominent specialists in the field of civil law in Latvia, authors consider that as a result of extensive interpretation of the legal norms and general legal principles, the application of analogy would be an effective temporary solution to ensure access to the immovable property. However, from the perspective of judges, this is probably a complicated and bold decision in terms of providing grounds thereto. Unfortunately, this is also demonstrated by the case-law. By decision on October 1, 2018 in case No. C73405818 Zemgale District Court judge rejected the request of "A.R.". It was stated that "[..] neither the cases regarding annulment or divorce of marriage nor cases arising from the custody rights and access rights, or restriction of trusteeship are in any way similar to cases regarding establishing a servitude of right of way. Furthermore, also the mentioned norms of the Civil Procedure Law [..] do not provide for such a provisional regulation [..." [30].

The ancillary complaint submitted by "A.R.” concerning the decision by Zemgale District Court judge was also rejected and left without amendments by Zemgale Regional Court in decision of 21 November 2018 in case No. C73405818. It is stated in the decision that "The fact that the Civil Procedure Law does not provide for a provisional regulation in other categories of cases, inter alia, establishing of servitude, cannot be recognised as a legislative gap that should be eliminated in accordance with the provisions laid down in Section 5, Paragraph five of the Civil Procedure Law. The court is not entitled to establish a provisional regulation in cases where the legislator has not established such a regulation. These matters are within the competence of the legislator" [31].

Considering the grounds for refusal stated in the decisions by Zemgale District Court and Zemgale Regional Court, authors conclude that the court, however, narrowly interprets the statutory provisions when examining the possibility to apply analogy. The following theses are stated in judgment of 14 February 2006 in case No. SKA - 34 of the Civil Cases Department of the Senate of the Supreme Court of the Republic of Latvia: "Thesis: The entity granting rights prior to considering the application of analogy must examine whether in the particular case it is possible to apply analogy at all [32]. In the analysed case the court based on the belief that analogy cannot be applied and this is not within the competence of the court. However, at the same time authors want to emphasise that "ECHR has declared that the first and foremost [..] requirement stipulated in Article 1 of Protocol No. 1 to the Convention is that any interference by a public authority with the right to property should be lawful" [33]. However, ECHR has not claimed that the legislator only has exclusive competence to impose restrictions on the right to property of a person. Also, other public authorities, inter alia, courts have such an entitlement, considering that the principle of legality is respected. Also, scientific literature states that the restriction of the right to property conforms to Article 1 of Protocol No. 1 to the Convention not only in the case it is prescribed by law, but also in the case where rights are restricted based on a law [34]. Thus, considering all conditions, also the court should have the entitlement to restrict the rights of "I.B.".

Having examined the specific nature of the application of analogy, current position of the court and the diversity of the cases related to the establishment of a servitude of right of way, authors conclude that reference to the application of analogy and the general principles of law in other cases related to the establishment of a servitude of right of way, most likely, would not yield the desired results. In view of the aforementioned, the authors believe that the Civil Procedure Law requires amendments that stipulate an entitlement of a court to determine a provisional regulation in the cases related to the establishment, alteration and termination of a servitude of right of way upon request of a party - allowing to take a provisional decision until the giving of a final judgment. 
It is not possible to define criteria in the law by which such decision ought to be taken. Consequently, the court would have to examine each individual request and the grounds thereof in compliance with the principles of proportionality, fairness, good faith and other principles. Furthermore, it will be necessary to examine whether the possibility to satisfy claim prima facie is more likely than the possibility of its rejection.

By simulating the situation where the owners of the dominant property bring a claim before a court wherein the court would have to examine the matter on taking a provisional decision and prima facia possibility to satisfy the claim, authors will illustrate this situation with the help of cases that frequently occur in practice. For instance, it is evident from documents and the actual situation that: 1) the dominant immovable property is surrounded by a wide and deep river, swamps or other immovable properties; 2) in order to access this property it is necessary to cross the servient immovable property as this is the only way to physically access the property; 3) already historically there is a road on the servient immovable property that leads to the dominant immovable property; 4) the road is used also by other neighbours and a servitude of right of way has already been established in favour of these immovable properties and recorded in the Land Register; 5) it is necessary to mention also such cases where there is even a remark on a servitude of right of way in the Land Register of the servient immovable property [35]; 6) the owner of the servient immovable property denies access to the road that at the same time is used by other neighbours and the owner refuses to conclude the contract on establishing a servitude of right of way. Authors are certain that, in such legal and factual circumstances, a court would have grounds to declare that the possibility to satisfy a claim prima facie is more likely than the possibility of its rejection. Moreover, there would be sufficient grounds for taking a provisional decision until the giving of a final judgment. Of course, it will be a completely different situation if a road suitable for walking and driving had not been constructed within the servient immovable property or there would be only a narrow path, or the owner of the dominant immovable property would be willing to establish a servitude of right of way at a specific location, although it could be established elsewhere where the owner of the servient immovable property is disturbed the least. By applying the modelling method, which is applied in the field of law quite rarely, authors reaffirm the aforementioned conclusion that it is not possible to define criteria in the law by which the provisional decision ought to be taken.

By outlining the described problem, authors want to launch debate on the necessity of a provisional regulation in cases related to servitudes of right of way. Consequently, potential amendments to the Civil Procedure Law are developed on a conceptual level. Authors propose to supplement the Civil Procedure Law with Section $230 .^{2}$ by including therein: 1) the definition of a provisional decision, because the respective notion has been used in the Civil Procedure Law (Sections 238. ${ }^{1}, 244 .{ }^{10}$ and 249. ${ }^{3}$ ) [36]), but it has not been defined; 2) when listing the cases subject to the submission of a request to take a provisional decision (already existent and cases on the establishment, alteration and termination of a servitude of right of way); 3) also to envisage a special scheme for the submission of a request and taking of a decision in cases related to the establishment, alteration and termination of a servitude of right of way (according to the principle stipulated in Sections 238. ${ }^{1}, 244 .{ }^{10}$ and $249 .{ }^{3}$ of the Civil Procedure Law).

Next question which draws authors' attention is related to the impact of insolvency proceedings and legal protection proceedings on the progress of the case on the establishment of servitude of right of way by a court. It should be noted that due to the limited length of this article the problems related to the impact of insolvency proceedings and legal protection proceedings are described briefly as authors plan to conduct an individual study for full disclosure of the respective problem. 
According to the legal norms laid down in the Insolvency Law [37], in situations where insolvency proceedings or legal protection proceedings of a natural or legal person are initiated, the debtor is deprived of the right of action in respect of the immovable property. This means that during the respective proceedings the debtor is prohibited from alienating the immovable property or encumbering it with property rights. The respective rights can be used if harmonised with the supervisory person of legal protection proceedings or by the administrator of insolvency proceedings. However, taking into account the overall activity of the mentioned persons, according to the purpose of the Insolvency Law - to promote the honouring of the obligations of a debtor in financial difficulties and, where possible, the renewal of solvency (Section 1 of the Law) [37], the encumbering of the immovable property of the debtor with a servitude of right of way in favour of another person or immovable property is not in the first position of the list of priorities. Also, the legal norms of the subjects of insolvency proceedings (natural and legal persons) that define the proceedings contain the following substance: this is an aggregate of measures of a legal nature, within the scope of which the claims of creditors are settled from the property of a debtor, in order to promote the honouring of the debtor's obligations [37]. Consequently, it can be concluded that the change of the owner of immovable property is inevitable that as an additional factor can complicate the progress of proceedings to establish servitude of right of way by a court. Thus, also creditors will have no interest in establishing servitude of right of way. For instance, one of the principles underlying the legal protection proceedings is that methods which restrict the interests of creditors more than required to restore solvency of the debtor must not be included in the plan of measures of legal protection proceedings. Encumbrances of the immovable property reduce the value thereof. Thus, cause a potential risk to creditors in terms of seeking to satisfy their claims to the fullest possible extent.

It should be noted that the minimal time frame for insolvency proceedings is set at six months, as stipulated in Section 111, Paragraph six of the Insolvency Law [37] in respect of the sale of the property of a debtor, Section 73, Paragraphs two and three of the Insolvency Law stipulates a period of six months during which creditors are allowed to submit claims, if the deadline specified in Section 73, Paragraph one of the Insolvency Law (one month) has been missed. However, the time period for implementation of legal protection proceedings can last even four years from the day of entering into effect of the court judgment regarding the implementation of the plan of measures of the legal protection. [37]. This can significantly prolong the legal proceedings in the dispute over establishing a servitude of right of way, because the debtor is not allowed to encumber the immovable property with property rights (except for cases where this is stipulated in the plan of measures of legal protection proceedings), and this is a restriction of the debtor's action during the implementation of legal protection proceedings [37].

\section{Conclusions}

During the study authors discovered that accessibility is one of the most important issues to be resolved within the scope of urban and rural development. This could partly be resolved by legislative changes (see Clause 4.2). Conceptual amendments regarding the introduction of a provisional regulation when taking a provisional decision in cases related to establishing (including alteration and termination of) servitude of right of way to the Civil Procedure Law proposed by authors, probably, in most cases will enable the owners of dominant immovable properties to continue their economic activity, as well as families to freely use their property without causing a particular burden or loss to the owners of servient immovable properties.

In respect of cases related to insolvency and legal protection proceedings it should be noted that the period of implementation thereof could prolong and hinder the process of 
establishing servitude of right of way. Unfortunately, there is no legislative act which defines the practice of the supervisory person of legal protection proceedings or the administrator of insolvency proceedings in particular in cases when servitude of right of way is to be established in respect of the debtor's immovable property.

\section{References}

[1] Pazingojums par Latvijas ilgtspējīgas attīstības stratēgijas lìdz 2030.gadam apstiprināšanu. 10.06.2010. Latvijas Vēstnesis, Nr. 101 (4293), 29.06.2010

[2] Latvijas ilgtspējìgas attīstības stratēgija līdz 2030.gadam (Latvija2030). 270.punkts. Available at: https://www.pkc.gov.lv/sites/default/files/inlinefiles/Latvija_2030_7.pdf

[3] Latvijas ilgtspējīgas attīstības stratēgija līdz 2030.gadam (Latvija2030). 270.punkts. Available at: https://www.pkc.gov.lv/sites/default/files/inlinefiles/Latvija_2030_7.pdf

[4] Eiropas pilsētu un regionu attīstība, lai tās kļūtu veselīgākas, drošākas un ilgtspējīgākas. 12.10.2017. (2018). Available at: http://www.vm.gov.lv/lv/ tava_veseliba/vides_veseliba1/eiropas_pilsetu_un_regionu_ attistiba_lai_tas_klutu_veseligak/

[5] Eiropas revīzijas palāta. İpašais ziņojums Nr.16/2017. (2017) Available at: http://publications . europa.eu/webpub/eca/special-reports/rdprogramming-16-2017/lv/

[6] Pētījums "Latvijas pilsētu sociāli ekonomiskās attīstības tendences" (2008) Available at: http://www.vraa.gov.lv/uploads/documents/petnieciba/petijumi/ Petijums_Latvijas\%20pilsetu\%20sociali\%20ekonomiskas $\% 20$ attistibas $\%$ 20tendences $1 . p d f$

[7] Valsts zemes diensts. Latvijas Nekustamā ìpašuma tirgus - statistiskie rādītāji. Available at: http://kadastralavertiba.lv/tirgus-dati/statistika/

[8] Likums "Par zemes lietošanu un zemes ierīcību". 20.panta trešāa daļa. Ziņotājs, Nr. 31/32, 15.08.1991., Zaudēja spēku 30.12.2009; likums "Par zemes privatizāciju lauku apvidos” 22.panta trešā daļa. Ziņotājs, Nr. 32/33/34, 20.08.1992

[9] Latvijas Republikas Satversme. 15.02.1922. Latvijas Vēstnesis, Nr. 43, 01.07.1993. Valdības Vēstnesis, Nr. 141, 30.06.1922

[10] Civillikums (1937). 1130.pants. Latvijas Republikas likums. Valdības Vēstnesis, Nr. 44, 24.02.1937

[11] Civilprocesa likums (1998). Latvijas Vēstnesis, Nr. 326/330(1387/1391), 03.11.1998

[12] Šks̄irējtiesu likums (2014). Latvijas Vēstnesis, Nr. 194(5254), 01.10.2014

[13] 2018. gada 9.septembra Līgums Par servitūta nodibināšanu nākotnē. (not published)

[14] Civillikums (1937). Latvijas Republikas likums. Valdības Vēstnesis, Nr. 44, 24.02.1937

[15] Обзор судебной практики по делам об установлении сервитута на земельный участок (утв. Президиумом Верховного Суда РФ 26 апреля 2017 г.) (2017). Available at: http: //www . supcourt.ru/documents/all/15912/

[16] Likums "Par tiesu varu” (1992). Ziņotājs, Nr. 1/2, 14.01.1993

[17] Latvijas Republikas Augstākās tiesas Senāta Civillietu departamenta 2017.gada 4.jūlija SPRIEDUMS Lieta Nr.C09030814 SKC 229/2017. Available at: http: / /at . gov.lv/lv/judikatura/judikaturas-nolemumu-arhivs/civillietudepartaments/hronologiska-seciba?year=2017

[18] Latvijas Republikas Augstākās tiesas Senāta Civillietu departamenta 2016. gada 12. Aprị̧̄a SPRIEDUMS Lietā Nr. C27209810 SKC-33/2016. Available at: 
http://at.gov.lv/lv/judikatura/judikaturas-nolemumu-arhivs/ civillietu-departaments/hronologiska-seciba?year=2016

[19] Latvijas Republikas Augstākās tiesas Senāta Civillietu departamenta 2014. gada 31.marta SPRIEDUMS Lietā Nr. SKC-11/2014. Available at: http://at. gov.lv/lv/judikatura/judikaturas-nolemumu-arhivs/civillietudepartaments/hronologiska-seciba?year=2014

[20] Latvijas Republikas Augstākās tiesas Senāta Civillietu departamenta 2013. gada 9.oktobra SPRIEDUMS Lietā Nr. SKC-458/2013. Available at: http:// at.gov.1v/lv/judikatura/judikaturas-nolemumu-arhivs/civillietudepartaments/hronologiska-seciba?year=2013, [viewed on 21.11.2018.]

[21] Latvijas Republikas Augstākās tiesas Senāta Civillietu departamenta 2009. gada 12.augusta SPRIEDUMS Lietā Nr. SKC - 192. Available at: http://at.gov.lv/ lv/judikatura/judikaturas-nolemumu-arhivs/civillietu-departaments/ hronologiska-seciba?year=2009, [viewed on 21.11.2018.]

[22] Latvijas Republikas Augstākās tiesas Senāta Civillietu departamenta 2005.gada 8.jūnija spriedums Lietā Nr. C39125103 SKC-320/2005. Available at: http:// at.gov.lv/lv/judikatura/judikaturas-nolemumu-arhivs/civillietudepartaments/hronologiska-seciba?year=2005, [viewed on 21.11.2018.]

[23] Cilvēka tiesību un pamatbrīvību aizsardzības konvencija. Eiropas Padome (EP). 04.11.1950. Ratificēts Latvijā 27.06.1997. Latvijas Vēstnesis, Nr. 143/144 (858/859), 13.06.1997

[24] Ministru kabineta 2007.gada 20.marta noteikumi Nr.182 "Noteikumi par nekustamā īpašuma objekta noteikšanu”, 16.1.punkts. Latvijas Vēstnesis, Nr. 50 (3626), 23.03.2007. Zaudēja spēku: 02.06.2011

[25] Ogres novada domes 2006.gada 27.aprīla saistošie noteikumi Nr.60 "Ogres novada teritorijas plānojuma grafiskā dala un Ogres novada teritorijas izmantošanas un apbūves noteikumi”. Pieejams Ogres novada domes arhīvā

[26] “A. R.” 2018.gada 26.septembra Lūgums Lietā Nr.C73405818 (par pagaidu lēmuma pieņemšanu civillietā par braucamā celsa servitūta nodibināšanu). (not published)

[27] “A. R.” 2018.gada 26.septembra Lūgums Lietā Nr.C73405818 (par pagaidu lēmuma pieņemšanu civillietā par braucamā ceļa servitūta nodibināšanu) (not published)

[28] “A. R.” 2018.gada 26.septembra Lūgums Lietā Nr.C73405818 (par pagaidu lēmuma pieņemšanu civillietā par braucamā ceļa servitūta nodibināšanu) (not published)

[29] E. Kalniņš Tiesību tālākveidošana // Privāttiesību teorija un prakse. Rīga: Tiesu namu agentūra, 319-320, lpp. (2005)

[30] 2018.gada 1.oktobra Zemgales rajona tiesas Lēmums Lietā Nr.C73405818 (not published)

[31] 2018.gada 21.novembra Zemgales apgabaltiesas Lēmums Lietā Nr.C73405818 (not published)

[32] Latvijas Republikas Augstākās tiesas Senāta Administratīvo lietu departamenta 2006.gada 14. februāra spriedums Lietā Nr. SKA - 34. Available at: http://at. gov.1v/lv/judikatura/judikaturas-nolemumu-arhivs/administrativolietu-departaments/hronologiska-seciba?year=2006

[33] Eiropas Cilvēktiesību tiesas spriedums: Iatridis v Greece, judgment of 25 March 1999, no.31107/96, ECHR 1999-II, para 58; Skrzyňski v Poland, judgment of 6 September 2007, no.38672/02, Available at: http://cmiskp.echr.coe.int/ tkp197/view . asp?item=1\&portal=hbkm\&action=html\&highlight=38672/02\& sessionid=17139593\&skin=hudoc - en 
[34] C. Grabenwarter, Europäische Menschenrechtskonvention. München, C.H. Beck, S. 365, 369, 370. (2005) Available at: http://www.satv.tiesa.gov.lv/ wp-content/uploads/2016/02/2008-11-01_Spriedums.pdf

[35] M. Auders, Pētījums par zemes reformas laikā ar administratīvo aktu nodibinātiem celsu servitūtiem. 7.lpp. (2014) Available at: http://petijumi.mk. gov.lv/sites/default/files/title_file/petijums_varam_2014_par\% 20zemes $\% 20$ reformas $\% 20$ laika $\% 20$ ar\%20administrativo $\% 20$ aktu $\%$ 20nodibinatiem $\% 20$ celu $\% 20$ servitutiem. DOCX

[36] Civilprocesa likums (1998). Latvijas Vēstnesis, Nr. 326/330 (1387/1391)

[37] Maksātnespējas likums (2010). Latvijas Vēstnesis Nr. 124 (4316), 06.08.2010, 40.panta 4.daļa, 49.pants, 63.pants 